\section{Plant Population Affects Yield and Fruit Size of Pumpkin}

\author{
Stephen Reiners ${ }^{1}$ \\ Department of Horticultural Sciences, New York State Agricultural Experiment \\ Station, Cornell University, Geneva, NY 14456-0462
}

Dale I.M. Riggs ${ }^{2}$

Cornell Cooperative Extension Capital District Vegetable Program, Albany Regional Office, 146 State Street, 4th Floor, Albany, NY 12207

Additional index words. Cucurbita pepo, plant density

\begin{abstract}
Field studies were conducted in 1996 on two pumpkin (Cucurbita pepo L.) cultivars, 'Howden' (vining-type growth habit) and 'Wizard' (semi-bush growth habit), at two locations to determine the effect of plant population and row width on marketable yield. Increasing plant populations from 2990 to 8960 plants per hectare resulted in significantly greater fruit number and yield at both locations and for both varieties. Average fruit size declined at the highest populations. Increasing row width from 1.8 to 3.6 $m$ resulted in a slight but significant decrease in number of fruit per hectare with no effect on other yield parameters. At one location, the effect of row width on yield and number of fruit per hectare depended on the population. At low populations, row width did not influence yield or fruit number; at high populations, wide rows produced lower yield and fewer fruit than narrow rows. The results demonstrate that growers may increase pumpkin yield by increasing plant populations but should use narrower row widths and wider in-row spacing. Growers who choose higher populations should ensure that all inputs are optimized to reduce potential plant-to-plant competition and use regionally adapted cultivars.
\end{abstract}

Acreage of pumpkins has grown considerably in the United States over the past 15 years. Although official statistics are not kept, it is estimated that $>2000$ ha are grown in New York State alone with a value $>\$ 25$ million in 1998. The majority of these pumpkins are grown solely for Halloween sales and are for decoration only, not for human consumption. Production practices have changed with the increase in acreage. At one time, pesticide inputs were very limited. Recent studies indicate that an effective disease control program may significantly increase the yield and quality of the crop (McClurg et al., 1992; Reiners, 1995). Weekly fungicide applications alone may cost growers $>\$ 400 /$ ha. In an effort to maximize profitability, growers are exploring ways to increase yield per unit area to reduce land, pesticide, fertilizer, labor, and machinery costs. Increasing the number of plants per hectare is one method that may accomplish this goal.

Received for publication 30 Oct. 1998. Accepted for publication 1 Mar. 1999. The research was funded in part by a grant from the New York State Vegetable Crops Statewide Program Committee. We thank Richard Ball, Schoharie, N.Y., for donating land and maintaining plots and Sarah Ball and Jim Ballerstein for their assistance in plot maintenance. The cost of publishing this paper was defrayed in part by the payment of page charges. Under postal regulations, this paper therefore must be hereby marked advertisement solely to indicate this fact.

${ }^{1}$ Assistant Professor; to whom reprint requests should be sent. E-mail : sr43@ cornell.edu

${ }^{2}$ Formerly Area Vegetable Specialist. Current address: D. Riggs, Consulting, Stone Wall Hill Farm, LLC, 15370 NY Rt. 22, Stephentown, NY 12168.
The relationship between plant population density and crop yield has been extensively studied for a number of horticultural crops. In an upper limit is reached for that species. At that point, competition between adjacent plants limits resources (Pant, 1979) and yields plateau or decline (Weiner, 1990). Yields of pumpkin were increased significantly by closer inrow spacing, especially in fields where soil moisture was optimized with timely irrigations (Reiners and Riggs, 1997). The increase in yield was attributed to greater numbers of fruit produced per unit area in the closely spaced plots. Although fruit in these plots were smaller than in the more widely spaced plots, the greater number of fruits resulted in higher yields. In other cucurbits, the results have been mixed. In watermelon [Citrullus lanatus (Thunb.) Matsum. and Nakai], two studies demonstrated that yield could be increased significantly using plant populations above the recommended spacings. NeSmith (1993) found that total yields increased in the high-density planting due to a greater number of fruit per hectare with only a slight decline in the average weight per fruit. Brinen et al. (1979) found that average fruit weight decreased while fruit number and total marketable yield per hectare increased as population density increased. Working with watermelon and muskmelon (Cucumis melo L.), Bracy and Parish (1997) found that yield per hectare was not significantly increased with closer in-row spacing. Studies on muskmelon in Indiana (Maynard and Scott, 1998), however, revealed that closer in-row spacing increased yield, but general, increasing plant population results in a greater yield per unit area for most crops until altering between-row spacing had little effect.

The growth habit of the species may play a role in determining the effect of spacing on yield. Generally, the recommended population density for semi-bush pumpkins is twice that for large vining types (Garrison, 1996). Reiners and Riggs (1997) demonstrated that there was little difference in yield between a semi-bush cultivar and a vining type. The only significant difference was seen in fruit number per hectare at the highest plant populations at one location. The authors hypothesized that the bushy growth habit was better able to exploit limited resources and reduce plant-toplant competition than the large vining type. Knavel (1991) evaluated short-internode (bush-type) muskmelons to determine if these could be grown at closer spacings than conventional muskmelons. His findings indicate that closer spacings did not increase yield. Similar results have been found with cucumbers (Cucumis sativus L.) (Widders and Price, 1989).

Growers have two options when increasing plant populations per unit area; either within-row or between-row spacings can be decreased. For pumpkin growers, a wider between-row spacing may allow easier access to fields for cultivation, and for pesticide or fertilizer applications. The objective of this research was to determine the effect of altering plant population by varying between-row and in-row spacing on the yield of two pumpkin varieties, one hybrid, semi-bush type and the other an open-pollinated, large vining type.

\section{Materials and Methods}

Experiments were conducted at two locations in 1996. The Geneva, N.Y., site was a Lima silt loam (fine-loamy, mixed, mesic, Glossoboric Hapludalf). The second site was located near Schoharie, N.Y., $\approx 300 \mathrm{~km}$ to the east. The soil type was a Barbour silt loam (loamy-skeletal mixed mesic Glossoboric Hapludalf). Both sites received banded applications of $\mathrm{kg} \cdot \mathrm{ha}^{-1} 44 \mathrm{~N}-40 \mathrm{P}-74 \mathrm{~K}$. Following banding, plots were hand-seeded $\approx 5 \mathrm{~cm}$ to the side of the fertilizer band and $3 \mathrm{~cm}$ deep on 5 and 6 June, at Geneva and Schoharie, respectively. 'Howden' (open-pollinated, large vining type) and 'Wizard' (hybrid, semi-bush type) pumpkins were planted in the field at varying plant spacings. The experimental design for both experiments was a split-split plot with row width the main plot, cultivar the subplot, and plant population the sub-subplot. All treatments were replicated three times. Row spacings were 1.8 or $3.6 \mathrm{~m}$. In-row spacings were $0.3,0.6$, or $0.9 \mathrm{~m}$ in the $3.6-\mathrm{m}$ plots and 0.6 , 1.2 , and $1.8 \mathrm{~m}$ in the $1.8 \mathrm{-m}$ plots, resulting in populations of 8960,4480 , and 2990 plants per hectare, respectively. Plots were three rows wide $\times 14 \mathrm{~m}$ long. All plantings were thinned to a single plant per hill. About 4 weeks after planting, when vines began to run, an additional $67 \mathrm{~kg} \cdot \mathrm{ha}^{-1} \mathrm{~N}$ (as ammonium nitrate) was sidedressed and shallowly incorporated. This resulted in a total $\mathrm{N}$ application of $112 \mathrm{~kg} \mathrm{ha}^{-1}$. Weeds were controlled using recommended herbicides, cultivation, and hand weeding. 
Insect and disease pressure was monitored and protective treatments applied when warranted (Garrison, 1996). Overhead sprinkler irrigation was used to supplement rainfall in the Geneva plots only.

A one-time harvest was made on 23 Sept. at Geneva and 25 Sept. at Schoharie. All pumpkins were harvested from the center rows of each plot, counted, and weighed. Only fruit that were orange, firm, and free from major blemishes or rot were considered marketable, while rotted and unripe fruit were considered unmarketable. To determine main effects, subplot, and sub-subplot effects and interactions, analysis of variance was used. Where treatment effects are significant $(<5 \%), P$ values are presented to indicate the level of significance. For significant interactions, regression analysis was performed and population effects were tested for linear correlations.

\section{Results and Discussion}

Plant population. The effect of plant population was significant at both locations for all yield parameters (Table 1). Fruit number increased $40 \%$ and $75 \%$ at Schoharie and Geneva, respectively, as plant population increased from 2990 to 8960 . These results agree with previous work, which found higher yields of pumpkins (Reiners and Riggs, 1997) and squash (Dweikat and Kostewicz, 1989) at closer in-row spacings. The greater fruit number resulted in a greater total yield despite a decline in fruit size (7\% and $21 \%$ at Schoharie and Geneva, respectively) as populations increased. The overall result was a significant increase in yield per hectare in both numbers and tonnage at the two locations.

The optimum plant population for the crop may be estimated by the yield parameter, fruit number per plant. At the lowest populations, plants at both locations averaged more than one fruit per plant. At the highest population, however, only $\approx 0.8$ fruits were produced per plant, indicating that $\approx 20 \%$ of the plants produced no fruit at all. Nonproductive plants are essentially weeds and merely serve to compete with more productive plants for available nutrients, water, and light. Optimal yield may be approached when each plant produces one or more fruit.

Row width. Row width had little effect on any aspect of yield, except for number of fruit per hectare, which increased at narrower row spacings at both locations. The greater number of fruit did not increase tonnage per hectare as the average fruit size declined slightly $(\approx 10 \%)$ with the narrow spacing. Interactions between row width and population at Schoharie indicate that row width may become more important at higher plant populations. The highest plant population resulted in greater fruit number and tonnage per hectare (Fig. $1 \mathrm{~A}$ and B). The effect was significant, however, only for the narrow row spacing. Narrower row widths provide each plant a more nearly square area of land than do wider spacings at the same population. Plants were spread out more evenly in the field and may have been less competitive with one another in this arrangement. The
Table 1. Yield of 'Wizard' and 'Howden' pumpkins grown at three plant populations and two row widths at two locations in 1996.

\begin{tabular}{|c|c|c|c|c|c|c|c|c|}
\hline \multirow[b]{3}{*}{ Treatment } & \multicolumn{8}{|c|}{ Location } \\
\hline & \multicolumn{4}{|c|}{ Schoharie } & \multicolumn{4}{|c|}{ Geneva } \\
\hline & $\begin{array}{c}\text { No. } \\
\text { fruit/ha }\end{array}$ & $\begin{array}{l}\text { Fruit no. } \\
\text { per plant }\end{array}$ & $\begin{array}{c}\text { Yield } \\
\left(\mathrm{t} \cdot \mathrm{ha}^{-1}\right)\end{array}$ & $\begin{array}{c}\text { Avg fruit } \\
\text { wt (kg) }\end{array}$ & $\begin{array}{c}\text { No. } \\
\text { fruit/ha }\end{array}$ & $\begin{array}{l}\text { Fruit no. } \\
\text { per plant }\end{array}$ & $\begin{array}{c}\text { Yield } \\
\left(\mathrm{t} \cdot \mathrm{ha}^{-1}\right)\end{array}$ & $\begin{array}{c}\text { Avg fruit } \\
\text { wt (kg) }\end{array}$ \\
\hline \multicolumn{9}{|l|}{ Row width (m) } \\
\hline 1.8 & 6252 & 1.27 & 52.8 & 8.7 & 6029 & 1.21 & 44.1 & 7.9 \\
\hline 3.6 & 5444 & 1.17 & 51.3 & 9.7 & 4915 & 1.00 & 39.6 & 8.6 \\
\hline Significance $^{z}$ & 0.0167 & NS & NS & NS & 0.007 & NS & NS & NS \\
\hline \multicolumn{9}{|l|}{ Cultivar } \\
\hline Howden & 5236 & 1.10 & 58.7 & 11.4 & 4483 & 0.89 & 44.1 & 10.4 \\
\hline Wizard & 6461 & 1.34 & 45.5 & 7.1 & 6461 & 1.33 & 39.4 & 6.2 \\
\hline Significance & 0.004 & 0.020 & 0.002 & 0.001 & 0.007 & 0.013 & NS & 0.001 \\
\hline \multicolumn{9}{|l|}{$\begin{array}{l}\text { Population } \\
\text { (no./ha) }\end{array}$} \\
\hline 2990 & 5004 & 1.67 & 46.4 & 9.6 & 3924 & 1.31 & 33.6 & 9.4 \\
\hline 4480 & 5335 & 1.20 & 48.6 & 9.2 & 5567 & 1.24 & 42.8 & 8.0 \\
\hline 8960 & 7207 & 0.80 & 61.4 & 8.9 & 6926 & 0.77 & 49.0 & 7.4 \\
\hline Significance & $\mathrm{L}^{* * * * *}$ & $\mathrm{~L}^{* * * * *}$ & $\mathrm{~L}^{* * * *}$ & $\mathrm{~L}^{* * *}$ & $\mathrm{~L}^{* * * * *}$ & $\mathrm{~L}^{* * * * *}$ & $\mathrm{~L}^{* * *}$ & $\mathrm{~L}^{* * * *}$ \\
\hline \multicolumn{9}{|l|}{ Interactions } \\
\hline $\mathrm{RW} \times \mathrm{C}$ & NS & NS & NS & NS & NS & NS & NS & NS \\
\hline $\mathrm{RW} \times \mathrm{P}$ & 0.04 & NS & 0.002 & NS & NS & NS & NS & NS \\
\hline $\mathrm{C} \times \mathrm{P}$ & NS & NS & NS & NS & NS & NS & NS & 0.016 \\
\hline $\mathrm{RW} \times \mathrm{C} \times \mathrm{P}$ & NS & NS & NS & NS & NS & NS & NS & NS \\
\hline
\end{tabular}

${ }^{2} P$ value from ANOVA; values $>0.05$ are considered nonsignificant (NS).

${ }^{* * * * * * * *}$ Significant at $P \leq 0.001$ or 0.0001 , respectively, for linear effects of population.

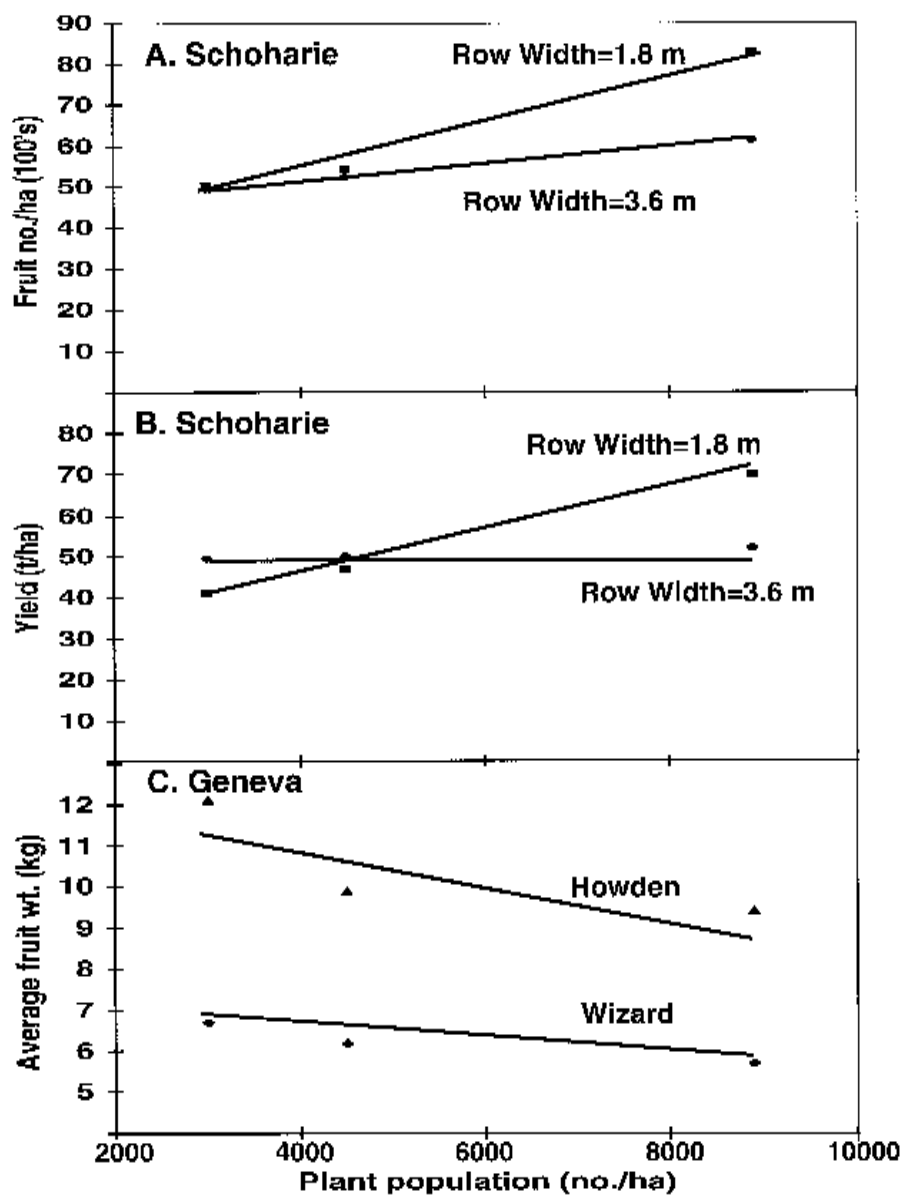

Fig. 1. Effect of population, row width, and cultivar on components of yield of pumpkin in 1996. (A) Effect of row width and plant population effect on fruit number at Schoharie, N.Y. Regression equations are: 1.8 -m row width $(\mathbf{\square}): \mathrm{Y}=31.56+0.00565 * \mathrm{X}\left(R^{2}=0.57, P=0.0003\right) ; 3.6-\mathrm{m}$ row width $(\mathbf{O}): \mathrm{Y}=43.75$ $+0.00195^{*} \mathrm{X}\left(R^{2}=0.47, P=0.05\right)$. (B) Effect of row width and plant population effect on tha ${ }^{-1}$ at Schoharie, N.Y. Regression equations are: $1.8-\mathrm{m}$ row width $(\mathbf{\square})$ : $\mathrm{Y}=25.9+0.005^{*} \mathrm{X}\left(R^{2}=0.53, P=\right.$ $0.0007) ; 3.6-\mathrm{m}$ row width $(\mathbf{O}): \mathrm{Y}=50.00+0.0024 * \mathrm{X}\left(R^{2}=0.38, P=\mathrm{NS}\right)$. (C) Effect of pumpkin cultivar and plant population effect on average fruit weight at Geneva, N.Y. 'Wizard' $(\bullet)$ : $Y=7.03+0.0002 * X$ $\left(R^{2}=0.27, P=0.03\right)$; 'Howden' $(\boldsymbol{\Delta}) \mathrm{Y}=12.74+(-0.0004 * \mathrm{X})\left(R^{2}=0.35, P=0.01\right)$. 
interaction was nonsignificant at Geneva, where yields were generally lower than at Schoharie. Perhaps this effect is more pronounced when yields are maximized with optimum inputs of fertilizer, irrigation, and pesticides.

Cultivar. 'Wizard' produced significantly more fruit per hectare than did 'Howden' but yields was reduced. Of more importance than cultivar differences, however, are possible interactions between cultivar, row width, and population. We hypothesized that 'Howden', with its large vining growth habit, may be more adversely affected by higher plant populations. The only significant interaction was on average fruit weight at Geneva (Fig. 1C). This interaction shows that fruit weight is more affected by population increases in 'Howden' than in 'Wizard', as previously observed with pumpkins (Reiners and Riggs, 1997). Given the lack of any other significant interactions with cultivar, the positive effect of increasing plant population on yield should hold true for both semi-bush types and large vining types. This agrees with work conducted in other vine crops (Knavel, 1991; Widders and Price, 1989).

These results indicate that increasing plant population will lead to a greater tonnage and number of fruit per unit area for both semibush and vining cultivars. Growers have the option of increasing plant population through narrower row spacing or closer in-row spacing. Based on these studies, our recommenda- tion is that the greatest benefit would occur with narrower rows and wider spacing within the row. This more nearly square arrangement appears to result in less competition between plants than the more rectangular arrangement with wide row spacings. While increased populations will result in greater yield, growers need to realize that average fruit size will be reduced. This overall effect seems to be true for both large vining pumpkin varieties like 'Howden' as well as semi-bush types like 'Wizard'. Competition for light, nutrients, and water would be increased in high-density plantings. In addition, closer spacings could increase leaf wetness, causing greater disease pressure. Growers who choose higher populations need to ensure that all inputs are optimized to reduce potential plant-to-plant competition and should use regionally adapted cultivars.

\section{Literature Cited}

Bracy, R.P. and R.L. Parish. 1997. Row number, seed spacing, and fertilizer rate effects on melon production. J. Veg. Crop Production 3(1)47-57.

Brinen, G.H., S.J. Locascio, and G.W. Elmstrom. 1979. Plant and row spacing, mulch, and fertilizer rate effects on watermelon production. $\mathrm{J}$. Amer. Soc. Hort. Sci. 104:724-726.

Dweikat, I.M. and S.R. Kostewicz. 1989. Row arrangement, plant spacing, and nitrogen rate effects on zucchini squash yield. HortScience 24:86-88.
Garrison, S.A. 1996. 1996 Commercial vegetable production recommendations. New Jersey Agr. Expt. Sta. Bul. E001L.

Knavel, D.E. 1991. Productivity and growth of short-internode muskmelon plants at various spacings or densities. J. Amer. Soc. Hort. Sci. 116:926-929.

Maynard, E.T. and W.D. Scott. 1998. Plant spacing affects yield of 'Superstar' muskmelon. HortScience 33:52-54.

McClurg, C.A., R.J. Rouse, and J.G. Kantzes. 1992. Evaluation of field performance and post-harvest quality of pumpkin, p. 135-138. In: P.A. Ferretti (ed.). Proc. 23rd Annu. Mid-Atlantic Veg. Workers Conf., Univ. of Delaware, Newark.

NeSmith, D.S. 1993. Plant spacing influences watermelon yield and yield components. HortScience 28:885-887.

Pant, M.M. 1979. Dependence of plant yield on density and planting pattern. Ann. Bot. 44:513516.

Reiners, S. 1995. Pumpkins, the big, the small, and the ugly-Variety trial results, p. 26-28. In: C. Petzoldt(ed.). Proc. New York State Veg. Conf., Cornell Univ., Ithaca.

Reiners, S. and D.I.M. Riggs. 1997. Plant spacing and variety affect pumpkin yield and fruit size but supplemental nitrogen does not. HortScience 32:1037-1039.

Weiner, J. 1990. Plant population ecology in agriculture, p. 235-262. In C.R. Carroll, J.H Vandermeer, and P.M. Rossett (eds). Agroecology. McGraw-Hill, New York.

Widders, I.E. and H.C. Price. 1989. Effects of plant density on growth and biomass partitioning in pickling cucumbers. J. Amer. Soc. Hort. Sci. 114:751-755. 